\title{
Sclerotic Fibroma: A Differential Diagnosis of Spontaneous Keloid
}

\section{Fibroma Esclerosante: Um Diagnóstico Diferencial de Queloide Espontâneo}

Rui Pedro Santos ${ }^{1}$, Cristina Resende ${ }^{1}$, Olga Ferreira ${ }^{1}$, Celeste Brito ${ }^{1}$

Autor Correspondente:

Rui Pedro Santos [drruisantos@hotmail.com] Rua Santa Bárbara n52, 4435-595, Baguim do Monte, Portugal

KEYWORDS: Fibroma; Keloid; Skin Neoplasms/diagnosis

PALAVRAS-CHAVE: Fibroma; Neoplasias da Pele/diagnóstico; Queloide

\section{CASE DESCRIPTION}

Sclerotic fibroma (SF) is a rare neoplasm first described in 1972 by Weary et al in association with Cowden syndrome. ${ }^{1}$ This rare syndrome typically manifests with mucocutaneous findings (trichilemmomas, verrucous papules in the oral mucosa, acral keratosis and sclerotic fibromas) and an increased risk for several neoplasms. ${ }^{1}$ Later, Rapini e Golitz coined the term solitary SF in the absence of Cowden syndrome. ${ }^{2}$ It is debatable whether SF is distinct lesion or a sclerotic evolutionary end-point of other conditions. ${ }^{3}$

SF manifests clinically as an asymptomatic, well-demarcated skin-colored to erythematous papule or nodule with no site or sex predilection. 2,3

The authors present a healthy 56-year-old male with a pink, linear plaque located on the left shoulder slowly growing for about 20 years. He was previously treated with intralesional corticosteroids for a suspected spon- taneous keloid but the patient abandoned treatment by his own initiative.

Physical examination revealed a firm, well demarcated, pink plaque measuring $15 \times 2 \mathrm{~cm}$ (Fig. 1). The distal part of the plaque had a digitiform, infiltrative border (Fig. 2). A skin biopsy revealed a well-circumscribed, non-encapsulated dermal nodule and hypocellular aggregation of collagen bundles in the mid dermis separated by distinctive clefts ("plywood-like" pattern). These findings are characteristic of SF. ${ }^{4}$

The patient denied any kind of local trauma, family history was unremarkable and there were not any other criteria of Cowden's syndrome.

Cryosurgery was initiated with partial regression in the 6-month follow-up.

This case has some unique particularities: the atypical keloid-like presentation and the remarkably wide dimensions and continuous growth which, in our perspec- 
tive, supports the hypothesis of SF as true neoplasm. We recommend that SF should be included in the differential diagnosis of spontaneous keloids.

No treatment is usually necessary but due to the necessity of histologic confirmation, surgical recession is the standard treatment. ${ }^{5}$ In our opinion however, cryosurgery seems to be an effective alternative.

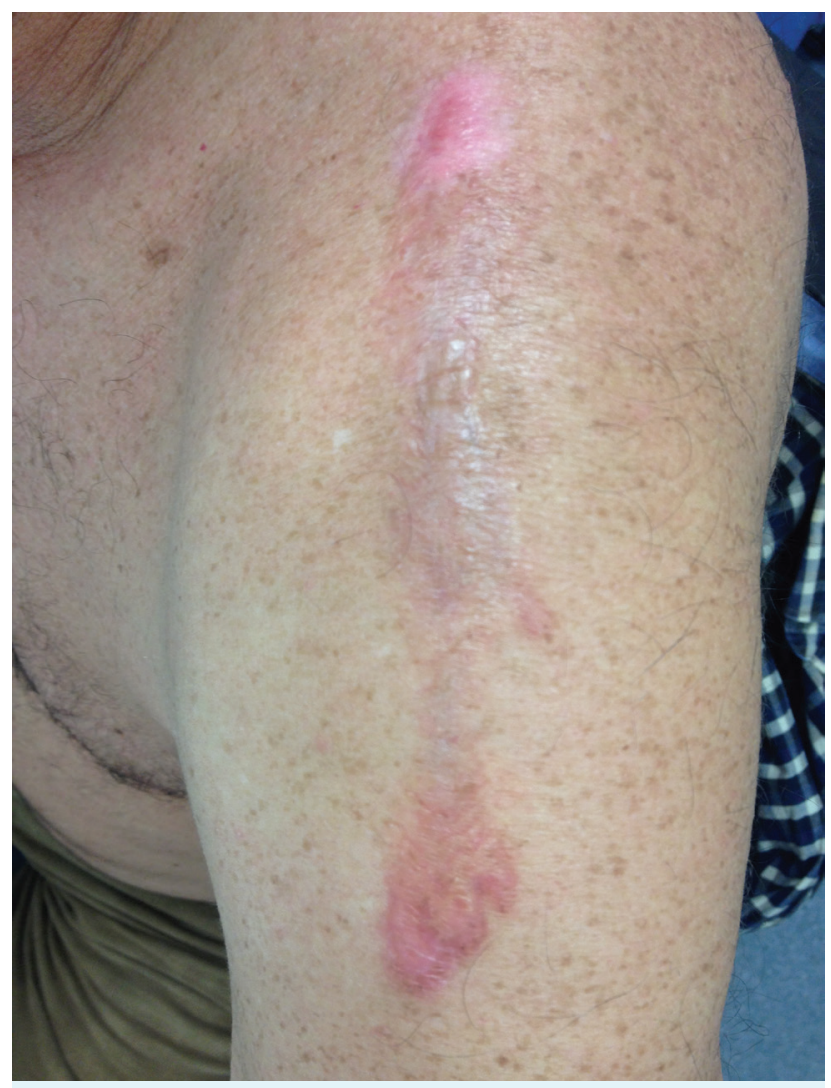

FIGURE 1. A firm, well demarcated, skin-colored to pink plaque along the left shoulder and proximal part of the upper limb.

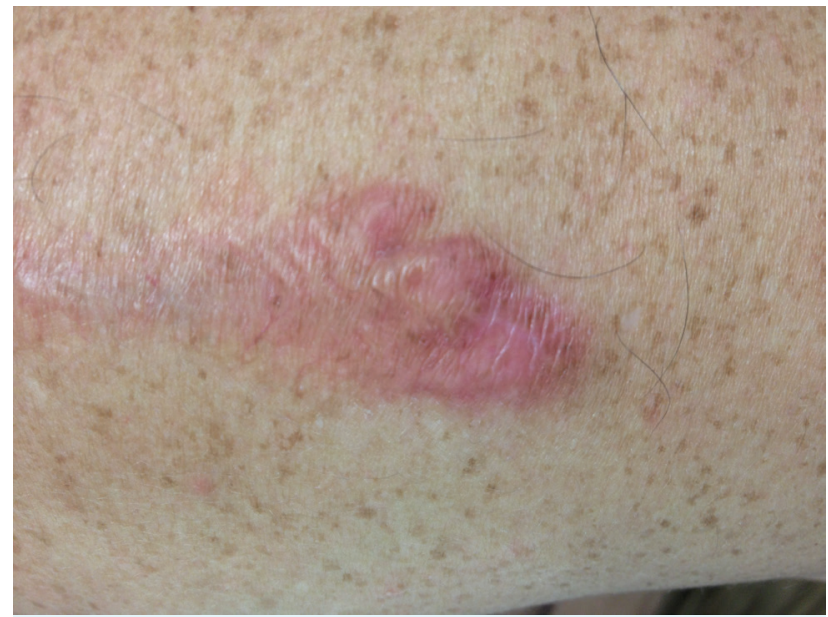

FIGURE 2. Note the digitiform active border of the lower part of the lesion.
CONFLICTS OF INTEREST: The authors declare that they have no conflicts of interest.

FINANCIAL SUPPORT: This work has not received any contribution, grant or scholarship.

CONFIDENTIALITY OF DATA: The authors declare that they have followed the protocols of their work center on the publication of data from patients.

PROTECTION OF HUMAN AND ANIMAL SUBJECTS: The authors declare that the procedures followed were in accordance with the regulations of the relevant clinical research ethics committee and with those of the Code of Ethics of the World Medical Association (Declaration of Helsinki).

CONFLITOS DE INTERESSE: Os autores declaram não ter qualquer conflito de interesse na realização do presente trabalho.

FONTES DE FINANCIAMENTO: Não houve qualquer fonte de financiamento na realização do presente trabalho.

CONFIDENCIALIDADE DOS DADOS: Os autores declaram ter seguido os protocolos da sua instituição acerca da publicação dos dados de doentes.

PROTEÇÃO DE PESSOAS E ANIMAIS: Os autores declaram que os procedimentos seguidos na elaboração do presente trabalho estão em conformidade com as normas das comissões de investigação clínica e de ética, bem como da declaração de Helsínquia e da Associação Médica Mundial.

\section{REFERENCES}

1. Weary PE, Gorlin RJ, Gentry WC, Jr., Comer JE, Greer KE. Multiple hamartoma syndrome (Cowden's disease). Arch Dermatol. 1972;106:682-90

2. Rapini RP, Golitz LE. Sclerotic fibromas of the skin. J Am Acad Dermatol. 1989;20:266-71.

3. High WA, Stewart D, Essary LR, Kageyama NP, Hoang MP, Cockerell CJ. Sclerotic fibroma-like change in various neoplastic and inflammatory skin lesions: is sclerotic fibroma a distinct entity? J Cutan Pathol. 2004;31:373-8.

4. Abbas O, Ghosn S, Bahhady R, Salman S. Solitary sclerotic fibroma on the scalp of a young girl: reactive sclerosis pattern? J Dermatol. 2010;37:575-7.

5. Stocchero GF. Storiform collagenoma: case report. Einstein. 2015;13:103-5. 